\title{
Thoughts on the Economic life of the Tathagata Buddha
}

\author{
Dr. Rakshit Madan Bagde, \\ Assistant Professor, \\ Late. Mansaramji Padole Arts College, Ganeshpur Bhandara \\ ORCID iD - 0000-0002-7507-0244 \\ Web of Science ResearcherID - AAF-2760-2020 \\ SSRN - Author ID: 4770534 \\ Authenticus ID - R-00J-YM2 \\ Vidwan-ID: 221858
}

\begin{abstract}
The economic system is the cornerstone of social development. Its economic system has remained at the root of the progressive development of human civilization. A country, society or caste; Social, political and cultural upliftment is mainly based on the progress of its economic resources and facilities. In a country without these facilities, human society cannot develop its civilization and culture. Meaning has a special place in human life. That is why even now and in the past, meaning is sometimes considered indirectly more important than religion. Gautama Buddha was the first to know this weakness of human nature. While stating that the root of all sorrows is desire, Gautama Buddha has also included materialism in desire. In his first sermon to the Panchaparivrajakas after attaining enlightenment at Sarnath, the Buddha says that there are two poles of human life. The first is the life of luxury and the second is the life of physical suffering. One says eat and drink and have fun because tomorrow we will all die, another says put an end to lust because lust is the reason for rebirth.

The Buddha rejected both ways of life because, according to him, both ways are unsuitable for human life. He believed in the middle way. This moderate path is neither for physical suffering nor for pleasure. The Buddha says, 'O Parivrajakas, understand that you should never imitate these two poles of life. Attempts to attain contentment through objects whose attraction is the desire for Kama Yoga are a despicable endeavor. They are unskilled. They are harmful. There is a way of life between these two poles, it is the middle way. I am a preacher of this middle way. The destruction of sorrow is the sole purpose of this Dhamma. 'This is the first Dhamma of Tathagata. Social misery is created out of a sense of superiority and inferiority. There are two extremes in the society: exploiter and exploited, rich and poor. Sorrow is created as soon as their ego of superiority is shaken. People who are stamped with inferiority complex are stuck in inferiority complex. So if the society wants to be happy, it is necessary to follow the middle way of life. Gautama Buddha conveys the message of 'equality' from the point of view of middle life, "Nekechi manussa settha na kechi manussa hina" that is, no man is superior or inferior. The beauty of human life is hidden in the Buddha's vision of equality.
\end{abstract}

Key words - Buddha, decent livelihood, wealth, trade, labor, charity, hunger and poverty, socialism

Research Methods - As the relevant study is of historical method, a secondary tool will be used.

\section{1) Samyak Ajivika -}


The 'Samyak Ajivika' of the Ashtanga path includes the Buddha's thoughts on economic life. Man has to earn his livelihood, there are many ways to earn this livelihood. Some inferior ways hurt others, others do injustice. The best way is not to hurt others, not to do injustice to others. The livelihood obtained in this great way is called 'Samyak Ajivika'. There were two philosophical schools of thought in the time of Buddha. The first of these is 'Yavajjivet sukh jivet rin kritva ghritam pivet' which means take out a loan and eat ghee roti while you are alive. The second is 'wishing for salvation by fasting.' Gautama Buddha opposes both streams of thought and says 'Majjimapatipada' is the middle way.

It is generally believed that the Buddha was just a religious great man, but this is not the whole truth. The social, economic and religious inequalities of the time gave rise to the egalitarian philosophy of the Buddha. The Buddha's discourse on financial matters was that the meaning should be used only in the welfare way. On the contrary, the wealth that we gain by using immoral means is certainly harmful to society. The fact that the Buddha included the righteous livelihood in the Arya Ashtanga path is still followed today. Adequate livelihood is not limited to the economic aspects of social life but is an indicator of the complete transformation of our overall collective life. It symbolizes the creation of an ideal society. Gautama Buddha preached the eightfold path for human welfare. Those eight principles are "Samyak Drishti, Samyak Sankalpa, Samyak Vyayam, Samyak Smriti, Samyak Vani, Samyak Karmat, Samyak Ajivika, Samyak Samadhi". This is the way to prevent suffering. That is the path to happiness.

The Buddha asked them to give up their lucrative ways of earning a living. This is a unique phenomenon in the development of Buddhism. The Buddha first revealed his aloofness from the wrong way of life. Gautama Buddha seems to have placed special emphasis on the two principles of morality and ethics in the matter of a decent livelihood. The Buddha's teachings are constructive. You can see in Buddhism the analysis of how a proper livelihood is important for a high ideal life.

\section{2) Thoughts about property -}

Gautama Buddha's views on wealth are reflected in his sermons from time to time. Wealth is the main means of worldly happiness. Wealth is needed to make oneself and one's family happy. Wealth donations are also needed. From greed comes greed, from greed comes lust-desire-insistence-mastery. Where there is no desire, there is no sense of ownership. The Buddha wants the Bhikkhus to inherit the Dhamma, not the material wealth. In the time of Buddha, the economic life of the people was happy and prosperous. Sonkotivinsh, the eldest son of a Champa resident, was a rich man of Rs 20 crore. Saket Seth 'Dhananjay' had made an ornament called 'Mahalata' worth Rs 90 million for his daughter 'Visakha', for which he had donated 5,400 cars. Also, for Visakha, her fatherin-law 'Mrigar Shrestha' had made an ornament for one lakh. Pippali Manavak had assets worth Rs 87 crore.

The Buddha divides wealth into four parts. He says, "Aken bhoge bhujjeyya, dvihi kamma payojaye. Chatutthachcha nidhapeyya, apadasu bhavistati, ti "means -

1) One part of the property should support you and your family.

2) Invest the second part of your wealth in your business.

3) Donate one third of the property.

4) A quarter of the property should be kept safe and protected for future calamities. 


\section{3) Agricultural Thoughts -}

The Buddha's time was one of the most prosperous in Indian history. Agriculture, crafts, trade were all at an advanced stage. Agriculture was the main occupation of Indians during the Buddha's time. According to the 'Jatak Kathe', the forest land was cleared and used for agricultural purposes. It was the duty of the king to make the seed available to the farmer on time. In the time of Buddha, agriculture was not a business of any one caste or religion. Ekna of Magadha used to cultivate the village Kashibharatdwaj with 500 plows. It was called 'Gramkrishi' to cultivate the whole village. Plowing was considered a nationally important task. Advising the farmer on how to cultivate, Gautama Buddha says, "First plow the field, sow the seeds in it, water it after sowing, cut it when the crop comes, grind it and remove the dust, beat it and combine the rest of the crop. Shakya people used to celebrate 'Vappamangal' festival for sowing seeds in the fields. In which a thousand plows were driven at the same time, the king himself used to drive the plow. This shows that agriculture was a glorious business at that time.

While preaching to Uday Brahman, the Buddha says that the farmer sows the seed again and again, it rains again and again, the farmer plows again and again. Agriculture was done properly. Wheat, linseed etc. For sowing of crops, sowing was considered better on Kartik, Panchami, Shashthi, Saptami of Shukla Paksha of Margashirsha. When it comes to sowing good seeds, Gautama Buddha says, Bhikkhunno! Like the seed of grain, like the seed of grape, sow it in wet soil; Whatever juice it absorbs from the soil, whatever water it absorbs will remain for sweetness. How come Bhikkhunno that seed is great. Farmers used to sow good yielding seeds for agriculture. In Machchajatak, Shasta refers to rain, saying that once there was no rain in Koshal region, agriculture dried up, where there were lakes and ponds. From this it is understood that irrigation means like wells, lakes, ponds, lakes are available. Clay pots were used to irrigate the fields. The task of agricultural safety is important. One of the incidents related to the security of agriculture in Lakhanjakat is that in the Magadha region, there was a danger from deer in the forest when the crop stood on the farm day. People used to dig pits in the farm yard to keep the deer away from the farm. Use catapults, traps. In this way the crop was protected from wild animals. Cows, oxen, camels, horses etc. for agricultural work. Animals were used.

Buddha views agricultural work with special respect. That is why they preach to earn a living through agriculture. In Buddhism, animal husbandry is mentioned as a side business besides agricultural work. The pastoralist was called by various names like Pashupalak / Gopalak / Gopal / Pashupal. People were also doing small to large scale industries.

\section{4) Business Ideas -}

In the time of Buddha, people used to do small and big industries and businesses to earn their

livelihood and earn wealth. In Buddhism, domestic and foreign trade was done. Many kinds of pots and pans which were useful but artistic were made by potters in the time of Buddha. The one who works in metal is called 'Kammar'. The blacksmith was called 'Lohkar' and the goldsmith was called 'Sonnakar'. Gautama Buddha tells how and what to do business. In this case, the business can be divided into two parts.

1) Improper business: - According to Gautam Buddha, such business which is harmful to the society becomes improper business. The Buddha includes the following occupations in explaining which are the inappropriate occupations. A) Animal slaughtering business. B) Luxury and non-essential businesses. C) Poison 
business. D) The business of manufacturing weapons of war. E) Ominous business. F) Occupational science of palmistry.

2) Proper occupation: - According to Gautama Buddha, all such occupations which are not harmful to the society are useful to the society. Proper business does not create mental stress. Businesses such as serving patients became fair business.

\section{4: 1 Currency -}

Currency system was prevalent in the time of Buddha. According to the Eightfold Path, a proverb in a palace was about 20 months and a foot was like five months. That is, the fourth part of a story is the foot. There was a saying of one foot of five masks and one foot of four feet. A pair of oxen would get twenty-four stories. A donkey used to get eight stories. A bundle of hay was a monthly and a worker's daily wage was a monthly or halfmonth. Coins of copper, iron, silver and gold were prevalent. Calling the Suvarnamudra Hiranya, the largest gold coin was 25 dams, or 10 ounces. Proverbs and masks are frequently mentioned in the Buddha's teachings.

\section{4: 2 Weights and Measures-}

In Buddhist times, 'Nali' was a popular measure for measuring food. The weight of the drain was $12^{1 / 2}$ pal. The small measure of food was the path. In the time of Buddha, there were other instruments for measurement, including Don, Tumb and Amman. Nali and Don are mentioned in the Buddha's teachings. Length and distance were measured in Buddhism during the time of Angul, Vidatti, Yatti, Kukku, Hatta, Usabh, Dhanu, Gavut, and Yojana. According to 'Abhidhanappadipika' 7 fingers $=1$ rattan, 7 rattan $=1$ yatthi, 20 yatthi $=1$ usabh, 80 usabh $=1$ gavut, 4 gavut $=1$ yojana, 1 yojana $=8$ miles. In Buddhism, religion was more important than earning a living. People in the society used to make money through religion. Even then there were two sides, the rich and the poor, but honesty was not lacking in economic life.

\section{5) Labor Thoughts-}

Buddhist India was prosperous. In the time of Buddha, people knew the importance of labor and in fact Buddhani had convinced it. The economic prosperity of a country depends not only on production but also on purity of mind and concentration. If the mind is not concentrated, it is not possible to produce a good quality product. The Buddha's strict command and instruction regarding production is that if a person is the food manure of the nation without doing any work, he should understand that he eats hot iron. An example of how Gautama Buddha was a proponent of labor prestige is that he reached Kashi Bharatdwaj at Eknala while plowing his field. When Kashi Bharatdwaj was giving food to his laborers, Kashi Bharatdwaj said to Buddha, "I eat by plowing, cultivating, sowing the land. Buddha Kashi told Bharatdwaja that I also farm but it is different and Buddha preaches to him. Impressed by the Buddha's teachings, Kashi Bharatdwaj fills a copper pot and gives kheer to the Buddha. But the Buddha denies it and says, "It is not right to subsist on mere preaching, the wise do not live on such food." From this you can understand how the Buddha also understood the importance of labor.

\section{6) Thoughts on property donation-}

Donation literally means 'giving'. Charity is the giving of goods or possessions that are given to the needy in a spirit of faith and power. There are four types of donations. 
1) Charity Donation - Well done charity.

2) Manual donation - to donate with one's own hands.

3) Chittikrit Dana - A heartfelt donation.

4) Unpaid donations - unbroken donations.

Gautama Buddha, while preaching to Vishakha about the good deeds of charity, said that giving alms to those who are deserving of charity is like sowing seeds in fertile soil. On the contrary, giving alms to those who are subject to rage and greed is like sowing seeds in the wrong land. The mental state of the person who accepts the donation stifles the development of the virtue, whatever the charity is given with a faithful mind and selfless attitude, the charity will be divinely sorrowful and pleasing. In the Dakshinavibhanga Sutta, the Buddha says Yo Silva Dussilesu Dadati Danam, Dhammen Ladden Supasanna Chitto. "Abhisaddhaham kammaphalen ullalar, sa dakkhina dayakato visujjati" means - the donor will be virtuous and virtuous, he will believe in his good deeds and believe in his good deeds, even if he donates to a vicious person, the benefactor benefits from good deeds.

\section{7) Thoughts on hunger and poverty -}

Gautama Buddha closely observed social life. In it, they see that man treats not only animals but also humans inhumanely. The question of food is always in front of every mind. Buddhani considers hunger to be the biggest disease as a hungry person will become aware of Dhamma. The Buddha never said that one should be blessed in poverty. Poverty is a blessing in disguise, and poverty is not something you will inherit from the earth. On the contrary, it is said to be prosperous. The Buddha says that poverty and debt are the greatest misery in life. The Buddha insisted that the pursuit of wealth should be modest. The Buddha protested against the heterogeneous society and said that everyone should do something to alleviate their poverty. The Buddha says that laziness is the biggest cause of poverty. Another cause of poverty is the misuse of money. The Buddha says that a portion of your income should be stored for times of crisis so that you do not have to take out a loan at that time.

\section{8) Socialism -}

The Buddha was vehemently opposed to the philosophy of the Vedas and Brahmans. The Buddha opposed the Vedas because the Vedas are as desolate as the desert. The Vedas hinder the formation of social values. According to the Buddha, freedom of thought is the most important thing. And freedom of thought is the only way to find the truth. Therefore, to believe that the Vedas are infallible means to deny freedom of thought altogether. The Brahmani social structure did not seem natural to the Buddha. She was interested in a particular community. The Buddha meant a free and independent society. Inequality in Brahmani society was class inequality. There was ascending hatred and descending hatred. The Buddha did not give priority to any imaginary, divine, soul, reincarnation, reality, truth, social equality, freedom of thought, the interests of all, etc. Gave importance to things.

While opposing heterogeneous social systems, the Buddha proposed the idea of neo-socialism. His idea of a new society was in the interest of people from all walks of life. A new society in which there is no suffering or injustice; Where the values of freedom, equality and fraternity are nurtured; In which virtue, cooperation and goodwill will increase mutual love. The Buddha's team did not discriminate between rich and poor, male and female, Brahmin and Shudra. There was no such thing as a dictatorship. A unanimous decision takes precedence. 
The Buddha was of the opinion that restrictions arising from social discrimination or inequality should be abolished.

\section{Conclusion -}

The Buddha says that if inequality is considered a natural law, it will be difficult for the weak to live. The Buddha teaches that the religion which preaches to increase one's own happiness as well as the happiness of others and not to tolerate any oppression is the supreme religion. Thus the Buddha rewarded social equality, freedom and justice through his Dhamma. The Buddha was the first socialist, egalitarian thinker in the world to cultivate social equality, freedom and justice. The ideological revolution of the Buddha is unmatched in history.

\section{References -}

[1] बोधी भदन्त राहुल (1996)- आदर्श बौद्धांची आचारसंहीता, भिक्खु संघाचे युनायटेड बुद्धिस्ट मिशन, मुंबई.

[2] बागडे रक्षित मदन (2019)-आंबेडकरांच्या आर्थिक विचारावर बुद्ध तत्वज्ञानाचा प्रभाव, लोटस आणि कोब्रा प्रकाशन नागपूर ISBN - 978-93-87250-25-3

[3] कौसल्यायन भदन्त आनन्द (1997)- अनुवाद भगवान बुद्ध और उनका धर्म, बुद्धभूमि प्रकाशन, नागपुर

[4] डांगे वंदना (2005)-भगवान बुद्धाचे आर्थिक जीवनाबद्दल विचार, लघुषोध प्रबंध, आंबेडकर विचारधारा विभाग रा.तू.म. नागपूर विद्यापीठ नागपूर

[5] उपाध्याय भरतसिंह (1991)- बुद्धकालीन भारतीय भूगोल, हिन्दी साहित्य सम्मेलन, प्रयाग.

[6] सिंह परमानंद (1996)- बौद्ध साहित्य मे भारतीय समाज, हलधर प्रकाशन, वाराणसी.

[7] सोनवणे आर. एस. (1995)- धम्मनिनाद, सुगावा प्रकाशन, पुणे. 